\title{
The Difficulty with Demarcating Panentheism
}

\author{
R. T. Mullins ${ }^{1}$
}

Published online: 21 January 2016

(C) The Author(s) 2016. This article is published with open access at Springerlink.com

\begin{abstract}
In certain theological circles today, panentheism is all the rage. One of the most notorious difficulties with panentheism lies in figuring out what panentheism actually is. There have been several attempts in recent literature to demarcate panentheism from classical theism, neo-classical theism, open theism, and pantheism. I shall argue that these attempts to demarcate panentheism from these other positions fail. Then I shall offer my own demarcation.
\end{abstract}

Keywords Panentheism - Classical theism · Neo-classical theism · Open theism · Pantheism

In certain theological circles today, panentheism is all the rage. Though the term 'panentheism' was coined in the nineteenth century, its contemporary proponents claim that it is an ancient concept of God that rivals more classical understandings of God and the God-world relationship. ${ }^{1}$ Proponents claim that panentheism offers a more theologically adequate understanding of God than other models of God because it is relational and dynamic. Many of its proponents further claim that panentheism is more apt at interacting with science than other models of God and the God-world relationship. ${ }^{2}$ However, these claims from panentheists might be premature. One of the most notorious difficulties for panentheism is its vagueness. ${ }^{3}$ It is incredibly difficult to pin down exactly what panentheism is and how it differs from rival models of God.

\footnotetext{
${ }^{1}$ (Lataster, 2014)

${ }^{2}$ Michael W. Brierley, 'The Potential of Panentheism for Dialogue between Science and Religion,' in (Clayton and Simpson, The Oxford Handbook of Religion and Science 2006). (Clayton, God and Contemporary Science 1997) (Peacocke 2007).

${ }^{3}$ Owen C. Thomas, 'Problems in Panentheism,' in (Clayton and Simpson, The Oxford Handbook of Religion and Science 2006).
}

R. T. Mullins

rtmullins@gmail.com

1 University of Cambridge, Cambridge, UK 
Panentheism is intended to be a mediating position between theism and pantheism. On theism, God and the universe are distinct, whereas on pantheism, God and the universe are identical. Panentheism wishes to take a via media by claiming that the universe is in God, but God is more than the universe. It is not clear, however, that panentheism actually offers us a clear and coherent alternative model to theism and pantheism for understanding God and the God-world relationship.

Allow me to illustrate. A few years ago, the World Parliament of Religions hosted a session on panentheism. Various contemporary panentheists gave papers discussing the major themes of this model of God. Others argued that particular historical thinkers should rightly be understood as panentheists instead of theists or pantheists. Overall, there was a celebration of the diversity of perspectives within panentheism. However, not all were able to celebrate. Patrick Hutchings was asked to chair the session. After chairing the session he reports to 'emerging no wiser than when I entered' as to what panentheism in fact is. ${ }^{4}$ He claims that if he were to commit himself to panentheism, it would not be clear that he would be committing himself to anything. ${ }^{5}$ Ultimately, Hutchings wants to know what exactly are the unique claims of panentheism that demarcate it from its rivals. He acknowledges that a religious movement or model of God can have a variety of perspectives within it, but he wants a definitive concept of panentheism that unites these diverse perspectives. Raphael Lataster acknowledges Hutchings' wish to have a definitive concept of panentheism yet does not offer one. In the midst of extolling the diversity within panentheism, Lataster claims that Hutchings 'wish might remain forever unfulfilled." 6

To add further vagueness to the concept of panentheism, recent discussions suggest that certain religious traditions that deny the existence of God should be considered under the banner of panentheism. ${ }^{7}$ It is not clear to me how one can be a panentheist and deny the existence of God. If one can deny the existence of God and be a panentheist, it is not clear to me what is not included in panentheism. The complaint of Hutchings should haunt the reader at this point: to commit oneself to panentheism is to commit oneself to nothing. ${ }^{8}$ For the purposes of this paper, I shall set aside panentheistic views that deny the existence of God and focus on views that affirm the existence of God. I only mention this to illustrate the rampant vagueness amongst contemporary panentheists. It seems that panentheism needs to offer a clear way of demarcating itself from other positions, and this is not something that contemporary panentheists have done. Nor is it clear that many are even interested in the task as the remark from Lataster suggests.

Yet this is a serious problem for panentheism, and its proponents should acknowledge it. If panentheism cannot be clearly demarcated from its rivals, it cannot justify its claims to be more scientific and theologically adequate. Nor can it justify its claims to be more relational and dynamic than theism. Further, if there is no definitive concept of panentheism, one cannot justify the claim that panentheism is an ancient idea found in the history of religious ideas. If panentheism is left as a vague and nebulous concept, all bets are off as to who in history is in fact a panentheist.

\footnotetext{
4 (Hutchings, 2010, 297)

5 (Hutchings, 2010, 299)

${ }^{6}$ (Lataster, The Attractiveness of Panentheism-A Reply to Benedickt Paul Gocke, 2014, 390)

${ }^{7}$ (Biernacki \& Clayton, 2014)

8 (Hutchings, 2010, 299)
} 
In this paper I shall argue that recent attempts to demarcate panentheism from its rivals are unsatisfactory. In 'Theological Models for God and the God-World Relationship' section of this paper, I shall briefly sketch the theological models that rival panentheism. These will fall under the headings of classical theism, neo-classical theism, open theism, and pantheism. Readers should note that I am following the classification schema in (Diller and Kasher 2013). ${ }^{9}$ This division of models of God is not of my own making, but it is quite widely held in contemporary discussions. I sketch these rivals before attempting to demarcate panentheism because there is quite a bit of agreement in contemporary discussions about how to demarcate these models of God from one another. Again, this is something lacking within panentheism. In 'Clayton's Demarcation of Panentheism and Pantheism Fails' section, Philip Clayton's attempt to demarcate panentheism and pantheism shall be critiqued. In 'Benedikt Paul Göcke's Demarcation of Panentheism and Theism' section, Benedikt Paul Göcke's attempt to demarcate theism and panentheism shall be critiqued. In 'Another Attempt at Demarcating Panentheism' section, I shall offer my own suggestions as to how panentheism might be demarcated from theism and pantheism.

\section{Theological Models for God and the God-World Relationship}

In contemporary philosophy of science, it is common to speak of competing research programs. Each research program will have a set of hard core theses that are not subject to revision, as well as a set of auxiliary hypotheses that are subject to revision. In this section, I shall treat each theological model as a research program by articulating the hard core of each program as well as some possible auxiliary hypotheses.

\section{Classical Theism}

The first model to examine is classical theism. This is the view of thinkers like Augustine, Boethius, Anselm, Peter Lombard, Thomas Aquinas, and the Catholic and Protestant Scholastics. The hard core of this model says that God is an a se, timeless, strongly immutable, simple, impassible, omnibenevolent, omniscient, omnipotent, and omnipresent substance. ${ }^{10}$ God exists a se iff God's existence does not depend upon anything other than Himself. God is a necessary being, and He does not derive His existence from anything else. God is timeless iff God necessarily exists without beginning, without end, without succession, without temporal location, and without temporal extension. God is strongly immutable iff God necessarily cannot undergo any intrinsic or extrinsic change. This includes mere Cambridge changes such as being referred to as Creator, Redeemer, Lord, and Judge of all men. God is simple iff God necessarily lacks any and all metaphysical complexity or diversity. Typically, this is characterized as all of God's attributes being identical to each other. However, strictly speaking, God does not have any properties, does not stand in any real relations to

\footnotetext{
${ }^{9}$ Readers will notice that I have not included process theism in this paper. Diller and Kasher have process theology as a distinct category from panentheism. Due to space limitations, I have chosen not to discuss process theology.

${ }^{10}$ (Augustine, City of God 1958, XI.10).
} 
creation, and lacks any potential. God is pure actuality. ${ }^{11}$ God is impassible iff necessarily God cannot suffer. God is pure uninterrupted joy. ${ }^{12}$ God cannot suffer any change and cannot experience anything other than uninterrupted and undisturbed joy. God is omnibenevolent iff God necessarily is perfectly good and loving. God is omniscient iff God necessarily knows all true propositions and has no false beliefs. God is omnipotent iff God necessarily can actualize any state of affairs that is logically and metaphysically possible. God is omnipresent in that all things are in His knowledge, power, and essence. All things are in God's essence, and God's essence is in all things. ${ }^{13}$ God is present to all in the act of knowing everything that exists and in the act of sustaining everything in existence. Given divine simplicity, God's knowledge is identical to His power, and His knowledge and power are identical to His essence. The act of sustaining everything in existence is identical to His act of knowing all things. Since God's eternity is identical to His act of knowing and sustaining all things in existence, all things that exist do so in God's eternity. ${ }^{14}$

In order to get a better grasp on the hard core of classical theism and its relationship to the created universe, one must consider some common auxiliary hypotheses amongst classical theists. Traditionally, most classical theists hold to a relational metaphysic of time where time exists iff change occurs. Change and succession are considered to be the characteristics of temporal substances throughout the Christian tradition. ${ }^{15}$ This is why classical theists say that God must lack succession and change in order to be timeless and strongly immutable. Further, classical theists traditionally hold to a presentist ontology of time where the present is the only moment of time that exists. The past no longer exists and the future does not yet exist. In conjunction with this, classical theists traditionally hold to an endurantist theory of persistence through time. Substances persist through time by existing as a whole, or all at once, at the times at which they exist. On endurantism there is numerical identity through time. For instance, the numerically same substance, Socrates, persists from birth to death as a whole. The substance that is Socrates does gain and lose various non-essential properties throughout his life, but it is the numerically same Socrates that persists throughout these changes. Given the commitment to presentism, any endurant object will exist as a whole, or all at once, at the present. Traditionally, classical theists would draw upon their commitment to endurantism and presentism to make sense of God's timeless eternity, immutability, and simplicity. ${ }^{16}$ They would say that God exists as a whole, or all at once, in a timeless present that lacks a before and after.

There are several other auxiliary hypotheses that classical theists disagree over. I shall note four that are relevant for our discussion. First, classical theists traditionally held to the eternality of truth. ${ }^{17}$ The essence of God generates a complete set of timeless propositions about the past, present, and future as well as a complete set of propositions

\footnotetext{
${ }^{11}$ For more details on timelessness, immutability, and simplicity see (Mullins, Simply Impossible: A Case Against Divine Simplicity 2013). (Lombard 2007, Dist. VIII.6).

12 (Keating and White 2009). (Wolterstorff 2010). (Arminius 1986).

13 (Lombard 2007, Dist. XXXVI-XXXVII).

14 (Aquinas Summa Contra Gentiles, I.66)

15 (Fox 2006, 226-7)

${ }^{16}$ Robert Pasnau, 'On Existing All at Once,' in (Tapp and Runggaldier 2011). Also, (Pasnau 2011, chapter 18).

17 (Dyer 2010)
} 
about all possible states of affairs. Most classical theists say that God has a perfect knowledge of Himself and thus knows all true propositions. This is why many traditional classical theists would say that God's knowledge does not change when creation comes into existence. God eternally knows all of the propositions about creation, and His knowledge is in no way based upon temporal affairs. ${ }^{18}$ The commitment to God's omniscience and the eternality of truth entails that God has exhaustive foreknowledge of the future. Although technically speaking, God does not literally foreknow, since God is timeless. Classical theists are committed to the eternality of truth, but some cash it out in different ways. In particular, some contemporary classical theists claim that God's knowledge is based upon the temporal universe. This is due to commitments over the second disagreeable auxiliary hypothesis.

The second auxiliary hypothesis is over temporal ontology. Earlier I noted that classical theists traditionally held to presentism and endurantism. Today that consensus is no more. Contemporary classical theists like Katherin Rogers, Paul Helm, and T.J. Mawson hold to an eternalist ontology of time and a perdurantist theory of persistence through time. ${ }^{19}$ On an eternalist ontology of time, all moments of time exist. The past, present, and future all exist. None ever pass out of existence, and none ever come into existence. On perdurantism, objects do not persist through time by existing as a whole. There is no numerical identity through time. Instead, objects persist through time by having temporal parts at each time at which they exist. ${ }^{20}$ Take the substance Socrates again. Socrates persists from birth to death by having different temporal parts at each instant of his existence. Given these commitments, classical theists like Rogers, Helm, and Mawson hold that God's knowledge is not just of Himself. Instead, God's knowledge is based upon a direct perceptual apprehension of the world. God knows all true propositions about the past, present, and future because $\mathrm{He}$ is eternally sustaining the past, present, and future in existence.

The third disagreeable auxiliary hypothesis is in regards to creation. Traditionally, the majority of Jewish, Christian, and Islamic classical theologians hold that the universe is not co-eternal with God. Nothing, they said, could be co-eternal with God. ${ }^{21}$ There was a state of affairs where God existed without the universe. God is a necessary being, and the universe is a contingent being. God need not create in order to be who He is. However, not all classical theists agree. Classical theists like Proclus and John Philoponus were split on this issue. Philoponus argues that God and creation are not co-eternal and that God's essence in no way depends upon creation. Proclus, however, argued that God must create in order to be who He is. One of his arguments goes like this. God is eternal, immutable, and simple. If creation is not co-eternal with God, but instead began to exist, God would undergo a change. He would become the creator. So God must eternally create an eternal universe in order to be who He is. ${ }^{22} \mathrm{~A}$ similar split took place within Islamic theology as well. Al-Ghazali defended the claim that the universe could not be co-eternal with God, whilst Avicenna and Averroes held that God must create in order to be who He is. ${ }^{23}$

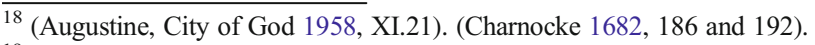

19 (Helm 2010). (Mawson 2005). (Rogers, Anselmian Eternalism: The Presence of a Timeless God 2007b).

20 (Hawley 2001).

21 (Blowers 2012, 154ff).

${ }^{22}$ For more on Proclus and Philoponus, see (Mullins, Divine Perfection and Creation Forthcoming).

23 (Rogers, Anselm and His Islamic Contemporaries on Divine Necessity and Eternity 2007a).
} 
In our own day, Rogers, Helm, and Hugh McCann also seem to disagree. Given their commitment to an eternalist ontology of time, there never is a state of affairs where God exists without the universe. The universe is co-eternal with God. Rogers, Helm, and McCann wish to maintain that the universe is contingent and that God's essential nature does not depend on the existence of the universe. However, it seems to be a clear entailment from their view that God must necessarily create the universe in order to be who He is. God is pure act and, as such, has no potential. If there are other possible ways that God could be, He would have unactualized potential. If it is possible that God create, then God must create. Otherwise, God would have unactualized potential. As such, Rogers and McCann explicitly hold that the only possible world is this world - the one where God and the universe are co-eternal. ${ }^{24}$ If this is the only possible world, the only way things can be, then it is necessary that it be this way. So the entailment from their model of God is one where it is necessarily the case that God and the universe are co-eternal. It might appear that this entailment arises from the combination of the hard core of classical theism with Rogers and McCann's auxiliary hypotheses, but I believe this is mistaken. Elsewhere, I have argued that the hard core of classical theism by itself entails the necessity of creation, but such arguments must be set aside until 'Benedikt Paul Göcke's Demarcation of Panentheism and Theism' section. $^{25}$ All that matters at this point is that classical theists disagree over whether or not God must exist with creation. They all agree, however, that the universe is comprised of a plurality of ontologically distinct substances that are created by God.

The fourth disagreeable auxiliary hypothesis is divine infinity. This is an attribute of God that not all classical theists have held in the past nor have all classical theists defined it in the same way. The concept of infinity has had a long and interesting history within theology, philosophy, and science. Not all classical theologians are willing to predicate infinity of God. Following Aristotle, theologians like Origen hold that God is finite. ${ }^{26}$ Why? Aristotelian philosophy says that an actual infinite thing is either impossible, unintelligible, or unknowable. ${ }^{27}$ God is knowable, so He must be finite. According to F. LeRon Shults, 'Origen had accepted the negative Greek idea of infinity and suggested that if God were infinite then God would not have the power to know God's self...God is known and therefore not "infinite". ${ }^{28}$ As Rogers notes, "the earlier medievals seem to steer clear of using the term infinite of God. Perhaps this is a hold over from the ancient association of "infinite" with "incomplete", "unfinished" and hence imperfect.' She goes on to point out that Anselm rarely uses the term infinite in reference to God, but by Aquinas' day it was common to predicate this attribute of God. $^{29}$

When classical theists do come to predicate infinity of God, this can mean several different things. The Thomistic understanding of divine infinity seems to mean that God is unsurpassable in His perfection and lacks all pontentiality. ${ }^{30}$ The Scotistic understanding of divine infinity has more nuance and means that God is the greatest

\footnotetext{
24 (Rogers, The Anselmian Approach to God and Creation 1997, 68-9). (McCann 2012, 170).

25 (Mullins, Simply Impossible: A Case Against Divine Simplicity 2013).

26 (Achtner 2005, 396).

27 (Oppy, 2014, 33).

28 (Shults 2005, 101).

29 (Rogers, Perfect Being Theology 2000, 11-12).

30 (Oppy, 2014, 34).
} 
of all beings. God is the upper limit of perfection. For John Duns Scotus, infinity is not an attribute of God, but a mode of God's attributes. ${ }^{31}$ God is infinite in two waysintensively and extensively. God being intensively infinite means that He will possess a perfection like goodness to an infinite/maximal degree. God's goodness is the upper limit of all goodness. God being extensively infinite means that He has all the compossible perfections one can have. These are not the only ways that God's infinity can be understood. As will be discussed below, pantheists have a different understanding of God's infinity that makes up part of the hard core of their model.

\section{Neo-classical Theism}

Neo-classical theists agree with much of the hard core of classical theism. ${ }^{32}$ They agree that God is a se, omniscient, omnipotent, omnipresent, and omnibenevolent. Part of the hard core of neo-classical theism is a rejection of divine timelessness, strong immutability, simplicity, and impassibility. Thinkers like Samuel Clarke, Nicholas Wolterstorff, Thomas Morris, William Lane Craig, and John Feinberg will say that God is eternal in that He exists without beginning and without end, but deny that God exists without succession. ${ }^{33}$ They reject strong immutability and instead opt for a weak immutability. God is weakly immutable iff God cannot change in His essential properties. God can change in regards to His relationships with creatures. For instance, God was not always the redeemer of humanity, but at one point in time became the redeemer of humanity. God's essential nature does not change in this process. God is necessarily good, and becoming the redeemer of humanity is a new expression of His goodness. Neo-classical theists reject divine simplicity and opt for divine unity. God's attributes are not identical to each other. Instead, God's essential attributes are distinct and coextensive. God's wisdom is not identical to His power, but one will not find God's wisdom floating free from His power. Further, a simple God is pure actuality. A simple God has no potential at all. Neo-classical theists say that God does have potential. An omnipotent God has the perfect potential to actualize any state of affairs that is logically possible and metaphysically compossible with who God is and what God has previously done. With regards to impassibility, neo-classical theists will either reject impassibility or hold to a weak impassibility. The end result is the same. God does have emotions, and He is disturbed by what occurs in the created universe. One might even say that God is maximally empathetic. ${ }^{34}$ However, God is never overtaken by His emotions. He never reacts in irrational ways due to His emotions. ${ }^{35}$

Like with the classical theists, the neo-classical theists disagree over various auxiliary hypotheses, and these disagreements shape the rest of their theology. Neo-classical theists seem to have the same set of auxiliary hypotheses as classical theists. For instance, they disagree over how to define God's infinity and human freedom. Craig holds to libertarian freedom and God's middle knowledge, whereas Feinberg holds to compatibilistic freedom and rejects God's middle knowledge. Yet they all agree on the eternality of truth to a particular extent. Neo-classical theists will hold that the eternality

\footnotetext{
31 (Scotus 1975, 5.10-11). (Cross 2005, 91 and 99-103).

32 Kevin Timpe, 'Introduction to Neo-classical Theism,' in (Diller and Kasher 2013).

33 (Clarke 1998). (Wolterstorff 2010). (Morris 1991). (Feinberg 2001). (Craig 2001).

${ }^{34}$ Linda Zagzebski, 'Omnisubjectivity,' in (Kvanvig, Oxford Studies in Philosophy of Religion 2009).

35 (Taliaferro 1989)
} 
of truth applies to the set of tenseless truths about creation and other possible worlds. These tenseless truths do not change their truth-value. There is also an eternal set of tensed truths, but the truth value of these tensed propositions is constantly changing as history unfolds. By way of example, take the tenseless truth $<$ Abraham Lincoln is the 16th president of the United States of America>. The truth-value of this proposition does not change over time, whereas the truth value of the tensed proposition $<$ Abraham Lincoln will be the next president of the United States of America $>$ does change over time.

This has an interesting entailment for the neo-classical theist's understanding of omniscience. The Neo-classical theist will agree with the classical definition of God's omniscience. However, since the truth value of tensed propositions is constantly changing, God's knowledge is also constantly changing. God eternally knew that $<$ Abraham Lincoln is the 16th president of the United States of America $>$ is true, but God did not eternally know that $<$ Abraham Lincoln is now the president of the United States of America>.

Most hold to a presentist ontology of time and an endurantist theory of persistence through time, though it is conceivable that a neo-classical theist could hold to a growing block ontology of time and a perdurantist theory of persistence. On a growing block ontology, the past and the present exist, but the future does not yet exist. As new moments of time come into existence, the previous moments of time do not cease to exist. The previous moments cease to be the present, but they do not cease to exist.

Neo-classical theists agree that God creates a plurality of contingent substances when God creates the universe. Most believe that creation is not co-eternal with God and that God's nature does not depend upon creation. However, Timothy O'Connor has argued that given God's omnibenevolence, there is a plentitude of love that will inevitably lead God to create an infinite number of universes. ${ }^{36}$ Given God's essential loving nature, God must create.

\section{Open Theism}

Open theism agrees with the neo-classical theist on the doctrine of God for the most part. To be discussed below, the biggest difference between open theists and classical and neo-classical theists is over the extent of God's knowledge. Open theists deny that God has exhaustive foreknowledge. Before delving into that issue, however, it should be noted that open theists take several things to be a part of their hard core that previous theists have as a part of their auxiliary hypotheses.

There are three hard core commitments that unite open theists. First, open theists are committed to presentism and endurantism. Second, they are committed to libertarian freedom. Third, they are committed to the claim that creation is not co-eternal with God and that God's essential nature is not dependent upon creation. ${ }^{37}$ In creating a universe, the necessarily existing God freely creates a plurality of contingent substances. ${ }^{38}$

\footnotetext{
36 Timothy O'Connor, 'Theism and the Scope of Contingency,' in (Kvanvig, Oxford Studies in Philosophy of Religion 2008).

37 (Hasker, Oord and Zimmerman 2011).

38 (Swinburne 1977, chapter 8). John Sanders, 'Divine Providence and the Openness of God,' in (Ware 2008, 197).
} 
As noted above, open theists deny that God has exhaustive foreknowledge. They all agree that God is omniscient, but they disagree over how to understand God's omniscience. Part of the disagreement is over the eternality of truth. ${ }^{39}$ Some open theists hold that there is an eternal set of truths about the way things are, will be, and could be, including a set of truths about the future. On this understanding the proposition $<$ Judy will eat a ham sandwich for dinner tonight $>$ is true. However, open theists of this sort will say that God does not know that it is true until Judy makes a ham sandwich, sits down, and starts eating. Open theists of this sort say that God's omniscience is not defined by knowing all true propositions since there are certain true propositions about the future that God cannot know. It is impossible, they will say, for God to foreknow what human persons with libertarian freedom will freely do.

Other open theists will find this implausible. Dean Zimmerman and Alan Rhoda contend that if a proposition is true, then God knows it. So instead of redefining omniscience, they reject the eternality of truth. Given the commitment to presentism, they argue that this entails that there is not an eternal, complete description of the world. There is a complete set of propositions about the past and the present, as well as a complete set of propositions about how the future might unfold, but there is not a complete set of propositions about how the future will in fact unfold. ${ }^{40}$ Propositions about the future like < Judy will eat a ham sandwich for dinner tonight $>$ do not have a determinate truth value of true or false. This does require one to give up the classical understanding of the logical principle of bivalence. ${ }^{41}$ The principle of bivalence says that for every proposition, the proposition has a determinate truth value of true or false. When one denies bivalence or restricts the scope of bivalence to propositions about the past and the present, she must offer a revised understanding of the laws of logic. This usually involves introducing a threefold truth-value scheme where propositions are either true, false, or indeterminate. It is not clear to me how successful such a revision can be, but I shall set that issue aside. ${ }^{42}$

\section{Pantheism}

The theistic views proposed above all agree that there is a plurality of substances that make up the world. God is a necessary being with certain essential properties, and creatures are contingent beings with certain essential properties. Pantheism denies that there is a plurality of substances that make up the world. Though it appears that there is a plurality of substances, this is an illusion since there is only one substance. As Ted Peters explains, 'Down deep, below the level of perception, all things are only one thing. That one thing is the divine reality. ${ }^{43}$ The one substance that exists is God. All else is a mode or manifestation of God. This comprises the hard core of pantheism.

Pantheists are united around this commitment, but they differ over what attributes God has. These differences comprise the auxiliary hypotheses of pantheism. For Spinoza, God is a supremely perfect being who exists necessarily and $a$ se, as well as timelessly eternal, simple, immutable, omnipotent, and infinite. Similar to what

\footnotetext{
39 (Rhoda, Boyd and Belt 2006).

${ }^{40}$ Dean Zimmerman, 'The A-Theory of Time, Presentism, and Open Theism,' in (Stewart 2010, 800-805).

${ }^{41}$ Alan R. Rhoda, 'The Fivefold Openness of the Future,' in (Hasker, Oord and Zimmerman 2011, 74-75).

${ }^{42}$ Craig Bourne, 'Fatalism and the Future,' in (Callender 2011, 46-60).

43 (Peters 2007, 281).
} 
Scotus held, Spinoza says that God is infinite in that He possesses all the possible attributes that exist, and God has all of His attributes infinitely. Given God's infinite power, Spinoza argues that an infinite number of things must necessarily flow from God in an infinite number of ways. An eternal and omnipotent God eternally displays His power by eternally bringing about all that can be brought about. ${ }^{44}$

Spinoza also defines infinity as unlimited. Finite things are limited by another thing of the same nature. A substance would be finite if another substance also existed. Since pantheists hold that God is infinite, it follows that no other substances can exist. The existence of other substances would limit God and thus make God finite. So the infinite God is the only substance that exists. ${ }^{45}$

There is a peculiar inconsistency in Spinoza's conception of God. In part 1 of the Ethics, Spinoza denies that God has an intellect and will, even though he says that God has thought. But in part 2 of the Ethics, Spinoza says that God has infinite intellect and infinite love. In part 5, Spinoza explains that the love of God is a love of Himself, and since we are of the same substance of God, it is also a love of us. This inconsistency in Spinoza is not something that all pantheists have.

Hegel goes against Spinoza by saying that God is the absolute Person. ${ }^{46}$ However, there is much debate as to whether Hegel is a pantheist or a panentheist. Both sides wish to claim him as their own. Regardless, other pantheists clearly affirm that God is a person whilst maintaining the hard core of pantheism-i.e. God is the only substance, and all else is a mode of God. The pantheist Don Lodzinski claims that God is an omniscient, omnipotent, timeless being with free will. God's knowledge is based on His contemplation of the universe/Himself. ${ }^{47}$ The pantheists William J. Mander and John Leslie say God is a conscious, omniscient, agent who knows the universe or multiverse. $^{48}$

Pantheists offer a variety of reasons for thinking this is true. Most of the arguments move from an element of classical theism and draw out an entailment to pantheism. One style of argument comes from Mander who argues from God's omniscience to pantheism. God is a perfect being who necessarily exists, is eternal, omniscient, omnipotent, and so on. Just like traditional classical theists, Mander says that God has a perfect knowledge of Himself and thus knows all things. From here, he develops his argument. 'A perfect being must know the world, yet a perfect being can only know itself (because a perfect being can only contemplate what is perfect). Therefore God must be identical with the world itself. ${ }^{49}$

\section{Panentheism}

With these rival models of God and the God-world relation laid out, one would hope that a better understanding of panentheism will emerge. As noted above, panentheists typically say that their position lies in between theism and pantheism. Yet, it is incredibly difficult to figure out what this in-between position is. What makes up the

\footnotetext{
44 (Spinoza 1910, part 1. Propositions XI-XXIV).

45 (Spinoza 1910, part 1. Propositions XIII-XV).

46 (Hegel 1975, 214).

47 (Lodzinski 1998).

48 (Mander, Does God Know What it is Like to be Me? 2002). (Leslie 2001).

49 (Mander, Omniscience and Pantheism 2000, 204).
} 
hard core of panentheism? Panentheists say that, unlike pantheism, God is not identical to the universe. Instead, God is more than the universe. In distinction from theism, panentheism will say that God is not utterly distinct from the universe. Instead, the universe is in God. What does it mean to say that the universe is 'in' God, but God is more than the universe? Critics of panentheism, like Göcke, acknowledge the difficulty with defining the 'in.' In fact, panentheists themselves typically acknowledge that the 'in' is a fuzzy concept and that there is no widespread agreement on its meaning. Yet, they maintain that it is still meaningful in defining panentheism. ${ }^{50}$

Following the work of Thomas Oord and Philip Clayton, Göcke notes many of the ways that panentheists typically try to distinguish themselves from theists by defining the 'in' in such a way that, supposedly, theists cannot affirm. Here are some examples: God energizes the world; God experiences the world; God ensouls the world; God plays with the world; God gives space to the world; God provides the ground of emergence in the world; God befriends the world. ${ }^{51}$ As Göcke and others point out, theists can easily affirm all of these claims. These accounts of the 'in' simply do not demarcate panentheism from theism.

Other attempts to define the 'in' claim that panentheists are affirming that one must use both immanent and transcendent metaphors when speaking of God. ${ }^{52}$ In other words, God is both immanent in creation and yet transcends creation. This is of little help with demarcating panentheism since all theists affirm that God is both immanent and transcendent. To make matters worse, many of the analogies, metaphors, and doctrines that panentheists use to define the 'in' are borrowed from theistic traditions. ${ }^{53}$ For instance, the panentheist Anna Case-Winters proposes that God's presence in the universe is sacramental. God is present in, with, and under all that exist. She is quite explicit that she is borrowing this sacramental presence from Reformed theology. ${ }^{54}$ To be clear, there is nothing wrong with borrowing doctrines, concepts, and analogies from other theological traditions in order to flesh out one's own systematic theology. It can be a fruitful enterprise. However, it does not help one demarcate her position from other theological systems, and that is precisely what the panentheist needs to do.

Here is another classic example. A common claim among panentheists is to draw upon the mind-body analogy borrowed from classical theism. ${ }^{55}$ The relationship between the mind and the body is analogous to, or a metaphor for, God's relationship to the universe. The claim is that the universe is God's body. However, it is not clear that this helps to demarcate panentheism since pantheists can easily say that the universe is God's body. Further, classical theists like T.J. Mawson also affirm that the universe is God's body. ${ }^{56}$ How can this be? How can seemingly different models of God all agree on this point? What are the substantive metaphysical claims that stand underneath the metaphor that comprises the hard core of panentheism?

According to Ankur Barua, the difference between a panentheist like Ramanuja and a classical theist like Augustine or an open theist like Richard Swinburne is over the

\footnotetext{
${ }_{50}$ Philip Clayton, 'Introduction to Panentheism,' in (Diller and Kasher 2013).

51 (Gocke 2013, 63). Cf. (Clayton \& Peacocke, 2004).

52 (Biernacki \& Clayton, 2014).

53 Owen C. Thomas, 'Problems in Panentheism,' in (Clayton and Simpson, 2006).

54 Anna Case-Winters, 'Rethinking Divine Presence and Activity in World Process,' in (Oord 2009, 69-70).

${ }^{55}$ Keith Ward, 'The World as the Body of God: A Panentheistic Metaphor,' in (Clayton \& Peacocke, 2004).

56 (Mawson, God's Body, 2006)
} 
definition of 'body'. ${ }^{57}$ All agree that God is the omnipresent sustainer of the universe, that God is present by His power and knowledge. Yet, they disagree over what counts as a body and the conditions for embodiment.

For Swinburne, there are five conditions that must be met for a mind to be embodied. The first condition is that the various goings-on of the physical body can cause pain or pleasure in the mind. Second, the mind can feel the inside of the body. An example would be the feeling of an empty stomach. Third, the mind can move the body through a basic action. A basic action is when an agent can perform an act without having to perform some other action in order to accomplish the first act. For instance, I move my arm by a basic act. I do not move the cup of water on my desk by a basic act. Fourth, the mind can look out from the world from where the body is. The body is the mind's locus of perception of the world. The mind acquires perceptual knowledge as mediated through the body. Fifth, the thoughts and feelings of the mind can be affected by the things that go on in the body. ${ }^{58}$

Ramanuja and Mawson only affirm conditions 3 and 4 as necessary for embodiment. In other words, their conditions for embodiment are satisfied by divine omnipresence. The universe counts as God's body because God consciously and causally sustains it in existence. Swinburne disagrees because he thinks all five conditions must be met for the universe to count as God's body. But surely the difference between panentheism and theism cannot be over what counts as a body. This is so because panentheism is supposedly making a unique claim about the nature of God, but nothing here says anything unique about God. To illustrate this, say Augustine or Swinburne weakened their stance on the conditions necessary for embodiment. They would become panentheists without having to change their doctrine of God and without having to change the way they say God relates to the universe. God would still be related to the universe via omnipresence.

This cannot be right. Surely something more substantive needs to be in place to demarcate panentheism from theism than the mere definition of embodiment. If mere omnipresence is all it takes for the universe to be God's body, then all forms of theism logically entail panentheism. Thus, there would be no difference between theism and panentheism, and as such this demarcation fails. Further, panentheists would then not be justified in their claim that panentheism offers a more theologically adequate model of God than theism. Recall from above that panentheists insist that their understanding of God is more dynamic and relational than theism. This would simply be false since theists would have the exact same model of God. It seems we still have not found out what demarcates panentheism from its rivals. What is the hard core of panentheism?

Below I will examine two recent attempts to demarcate panentheism from its rivals. First, I shall examine an attempt from Philip Clayton to demarcate panentheism from pantheism. Then, I shall examine an attempt from Benedikt Paul Göcke to demarcate panentheism from theism. I shall argue that each fails before making a few suggestions about ways forward.

\footnotetext{
57 (Barua, 2010)

58 (Swinburne, 1977, 102-4).
} 


\section{Clayton's Demarcation of Panentheism and Pantheism Fails}

Again, panentheism is supposed to be a position that lies in between theism and pantheism. Philip Clayton attempts to demarcate panentheism from pantheism by employing Charles Hartshorne's method for modeling God. ${ }^{59}$ This method for modeling God involves answering five questions. Is God eternal? Is God temporal? Is God conscious? Does God know the world? Does God include the world? A letter is assigned to an affirmative answer for each question: $\mathrm{E}=$ eternal; $\mathrm{T}=$ temporal; $\mathrm{C}=$ conscious; $\mathrm{K}=$ God knows the world/universe; $\mathrm{W}=$ God includes the world/universe. Say one is a classical theist and believes that God is eternal, but not temporal, and that $\mathrm{He}$ is a conscious knower of the universe. Your model of God would be an ECK. On Hartshorne's understanding, panentheism is an ETCKW. Hartshorne and Clayton take Spinoza to be the prime example of pantheism and say that it is an EW.

I believe that there are some difficulties with this method of modeling God, but I shall only mention one crucial problem. Donald Wayne Viney points out that it is not clear what 'world inclusion' means. ${ }^{60}$ The phrase is left undefined by Hartshorne. Without a clear understanding of world inclusion, it is not obvious what distinguishes panentheism from theism or pantheism. On some models of world inclusion, it looks like anyone who affirms divine omnipresence will get a $\mathrm{W} .{ }^{61}$ That simply will not be enough to demarcate panentheism from theism, let alone from pantheism. More needs to be said about world inclusion. (I offer my own suggestions in the 'Another Attempt at Demarcating Panentheism' section.)

Clayton tries to give some definition to world inclusion. According to him, the world is comprised of one substance. This one substance is God. Although it appears that there are many separate, discrete, individual substances, this is an illusion. Everything is really a mode, manifestation, or expression of the one substance, which is God. ${ }^{62}$ At this point, one might recall the discussion of pantheism above and form the belief that Clayton is espousing the hard core of pantheism. Clayton will disagree. The difference, according to Clayton, between pantheism and panentheism is that pantheism only holds to EW, whereas panentheism holds to ETCKW. Clayton would say that pantheism and panentheism have a lot in common, but the pantheist God is not a temporal, conscious knower. This is what demarcates panentheism from pantheism.

Does this demarcation actually work? No. This schema says that Spinoza's pantheism is an EW. As discussed above, there are passages where Spinoza attributes things like consciousness and knowledge to God. So there is more to Spinoza's pantheism than EW. Spinoza's God looks more like an ECKW. What about temporality? Clayton maintains that Spinoza only allows temporality for the modes of God but not for God Himself. ${ }^{63}$ I find this baffling because the modes are modes of God. If a mode changes, God changes because the mode is a manifestation, or expression, of God. God expresses Himself one way at one time in the mode Socrates and expresses Himself another way at another time in the mode Bill Clinton. In the process of divine

\footnotetext{
59 (Clayton, Panentheisms East and West 2010).

${ }^{60}$ Donald Wayne Viney, 'Relativising the Classical Tradition: Hartshorne's History of God,' in (Diller and Kasher 2013, 67).

61 (Barua, 2010)

62 (Clayton, Panentheisms East and West 2010, 185).

63 (Clayton, Panentheisms East and West 2010, 186).
} 
expression, God would undergo change and thus be temporal. So Spinoza's pantheism should be an ETCKW. What, then, is the difference between pantheism and panentheism?

More importantly, Clayton seems to assume that Spinoza's pantheism is representative of all types of pantheism, but this is false. Say that Spinoza really does only hold to EW. Other pantheists will disagree and say that God is ETCKW. Recall from above Mander's argument from divine omniscience to pantheism. On Mander's pantheism, God is a conscious knower who knows all things, including temporal changes. So Mander's pantheism is ETCKW. Again, what distinguishes pantheism from panentheism? Clayton's proposed demarcation fails to point out the hard core of panentheism.

\section{Benedikt Paul Göcke's Demarcation of Panentheism and Theism}

Earlier I mentioned that Göcke finds most proposals for demarcating panentheism unsatisfactory. He notes other attempts to demarcate panentheism from theism and explains why they fail as well. For instance, one attempt at a demarcation is to say that classical theism maintains that God does not change nor is He influenced by the universe. Panentheism, according to this demarcation, does say that God changes and is influenced by the universe. Göcke says that this demarcation fails because neither classical theists nor panentheists believe that God is one being amongst other beings, so on neither view is God influenced by the universe. ${ }^{64}$

While I agree that this does not demarcate theism from panentheism, I maintain that this claim from Göcke is false for at least two reasons. First, as noted above, there are theists who say that God is influenced by the universe. Granted that Göcke only has in mind classical theism, but there are more theisms than classical theism as is widely discussed in contemporary debates. Second, there are many panentheists who hold that the universe influences God and that God is one being amongst many. For instance, Philip Clayton and Arthur Peacocke are two of the most prominent contemporary panentheists, and each claims that God is influenced by the universe. ${ }^{65}$ Regardless, I agree with Göcke that this attempted demarcation between theism and pantheism fails but for a different reason.

Göcke's claim that the panentheist God does not change is false. Panentheists maintain that their understanding of God is dynamic and relational, whilst the God of theism is static and aloof. ${ }^{66}$ However, the panentheist claim that the theistic God is static and aloof is false. It is true that the God of classical theism does not change and is not influenced by the universe, but this is not true of neo-classical theism or open theism. Neo-classical and open theists have a God that is dynamic, relational, and changes as He continually interacts with the created universe. Nothing about God being dynamic, relational, and changing demarcates panentheism from theism. So we still do not have a clear account of panentheism.

\footnotetext{
64 (Gocke 2013, 72).

65 (Clayton, God and Contemporary Science 1997). (Peacocke 2007).

${ }^{66}$ (Biernacki \& Clayton, 2014).
} 
Göcke believes that he can give a clear definition of panentheism and offers a sound reason for rejecting panentheism. His proposal is that classical theism and panentheism differ only over the modal status of the world. According to Göcke, panentheism says that the world is an intrinsic property of God. So, necessarily, there is a world. On classical theism, the world is an extrinsic property of God's. The world exists contingently. With this distinction in hand, Göcke explains that as long as we do not have an argument for the necessity of the world, we do not have reason to think that panentheism is true. ${ }^{67}$

In an effort to be clearer, some of Göcke's language can be cleaned up. ${ }^{68}$ First, I believe that Göcke should say 'universe' and not 'world.' A universe is a spatiotemporal collection of physical objects that is not spatially, temporally, or causally related to any other such spatiotemporal collection of physical objects. A world is a maximally compossible state of affairs. There is a possible world where God exists alone. There is a possible world where God and a universe exist. There is a possible world where God and a multiverse exist. ${ }^{69}$ With these distinctions between worlds and universes in hand, one can see why Göcke should not speak in terms of the modal status of the world. To say that the world necessarily exists is trivial because a world of some sort must exist. Instead, Göcke should say that the difference between theism and panentheism is over the modal status of the universe. Panentheists, on Göcke's account, should say that the universe is a necessary property of God.

Yet this does not seem quite right either. A universe cannot be a property. A universe is a concrete object or collection of concrete objects, and properties are abstract objects. It seems that Göcke wishes to say that the universe exists of necessity on panentheism. But is Göcke trying to get at something more with the claim that the universe is a property of God's? I don't think so. Göcke continually says that God's relationship to the world (read: universe) is a necessary relationship. Some might think that the claim that the universe is an intrinsic property of God's is an attempt to say something more than this. It seems like Göcke is trying to get at the ever elusive 'in' of panentheism. Perhaps, one might suggest, that Göcke is really trying to say that the universe is a proper part of God. ${ }^{70}$ But Göcke explicitly says that the panentheist should not opt for a mereological approach to God and the universe. ${ }^{71}$

I am in full agreement with him on this point since a mereological approach fails for the exact same reason that we saw above with embodiment: it does not tell us anything unique about God. Mereology could be part of the metaphysical story of panentheism, but it certainly does not get at the heart of demarcating panentheism. At most, a mereological approach will tell us something unique about mereology. Say that the panentheist holds to an unrestricted composition such that God and the universe comprise a larger whole. Any theist could adopt this mereology without changing her doctrine of God. Changing the mereology does not capture the panentheist's claim to

\footnotetext{
${ }^{67}$ (Gocke 2013, 61).

${ }^{68}$ It should be noted that some of this language is cleared up in Gocke, Another Reply to Raphael (Lataster, 2015). However, for a deeper understanding of his own account see Gocke, A Theory of the Absolute, (2014a).

69 (Kraay, Theism, Possible Words, and the Multiverse 2010).

${ }^{70}$ In his reply to Lataster, he makes this suggestion but remains sceptical that this is a way to demarcate panentheism. (Gocke, Another Reply to Raphael Lataster, 2015)

71 (Gocke 2013, 68).
} 
have a more theologically adequate understanding of God. So it seems to me that Göcke is justified in dismissing mereological approaches to panentheism as the way to demarcate panentheism.

What, then, is Göcke saying? It seems that the only claim being made here by Göcke is that panentheism says that the universe necessarily exists whereas theism says that the universe contingently exists. What is one to make of this demarcation of panentheism and theism? Does it clearly distinguish theism from panentheism? No. I shall offer three reasons for thinking that this demarcation fails.

First, as noted above, classical theists like Rogers and McCann explicitly hold that there is only one way the world could be. The actual world is the only possible world. Elsewhere I have argued that classical theism's commitment to divine simplicity entails that there is only one possible world. ${ }^{72}$ There are several ways to develop this argument, but here is the quickest way to do so. On divine simplicity, God's essence is identical to His existence. Also, God's one simple act is identical to His essence/existence. God's act of creating the universe is identical to this one simple act, and so identical to God's essence/existence. God exists of absolute necessity. So, His act of creation is of absolute necessity since it is identical to His essence/existence.

Certain classical theists will be quick to respond by saying that creation only exists of conditional necessity, but this is false. If God's act of creation is of conditional necessity, His act is not identical to His essence. This is so because conditional necessity is not identical to absolute necessity. So if the classical theist makes this move, she will be abandoning divine simplicity because she will be forced to say that God's act is not identical to God's essence. Since simplicity is part of the hard core of classical theism, this is not a move open to classical theism.

Again, the actual world is the only possible world. The actual world contains a universe. It may contain a multiverse. I am not certain, but it certainly contains this universe. So on classical theism, the modal status of the universe is necessary. Even a neo-classical theist like Timothy O'Connor argues that it is inevitable that God creates the multiverse. ${ }^{73}$ The neo-classical theist Klaas Kraay has argued that the only possible world is one in which God creates a multiverse. Kraay is explicit that this entails a modal collapse, so God's relationship to the multiverse is necessary. ${ }^{74}$ So, the modal status of the universe does not distinguish classical and neo-classical theism from panentheism. Each seems to hold that the modal status of the universe is necessary.

Second, not all panentheists think that the modal status of the universe is necessary. Thomas Jay Oord holds to a weaker claim - it is necessary that God exist with a universe of some sort, but it is not necessary that God exist with this universe. In order to understand this weaker claim, it should be noted that Oord denies the doctrine of creation ex nihilo. God creates ex chaosmos. There is a co-eternal chaotic cosmos that is intimately related to, and dependent upon, God. God creates an orderly universe out of this chaotic cosmos. Given God's loving nature, God is always creating a universe of some sort. Oord proposes a cyclical cosmology on which an orderly universe comes into existence through a big bang, runs its course, and eventually collapses and gives rise to a new big bang that starts another universe. This process of expanding and

\footnotetext{
72 (Mullins, Simply Impossible: A Case Against Divine Simplicity, 2013)

73 (O’Connor 2012, chapter 5).

74 (Kraay, Theism and Modal Collapse 2011).
} 
collapsing universes is eternal. On this account, God does not have to exist with a particular kind of universe, but God must exist with a universe of some sort. ${ }^{75}$ The claim that a loving God must create a universe of some sort looks strikingly similar to claims made by the neo-classical theist O'Connor. As noted above, O'Connor argues that it is inevitable that a loving God will create a universe of some sort. God's love overflows in a creative act that produces a multiverse. So panentheists and neo-classical theists can both maintain that God must exist with a universe of some sort. So, nothing here clearly demarcates panentheism from theism.

Third, not all panentheists hold that God must exist with a universe of some sort. Philip Clayton, the leading contemporary panentheist, says that God freely created the universe. The universe is contingent and has not always existed. God existed before and without the universe. God created the universe ex nihilo. The universe is not the inevitable outcome of the divine nature. ${ }^{76}$ So on Clayton's panentheism, the modal status of the universe is contingent, not necessary. Göcke's demarcation fails to correspond to the views that panentheists espouse. Further, most of the theists described above agree with Clayton's doctrine of creation. So, nothing here demarcates theism from panentheism.

But there may be a rejoinder to my arguments. Say that Göcke insists upon his demarcation of theism and panentheism. Perhaps one might say that these classical and neo-classical theists who affirm that God must create a universe are really just panentheists in disguise. That would be rather odd. Do we really wish to say that Thomas Aquinas, Rogers, McCann, O'Connor, and Kraay are all closet panentheists? That seems to strain credulity. Also, since there are panentheists themselves who do not insist that God must create, one could complain that Göcke's demarcation is simply not accurately capturing the hard core of theism or panentheism. In other words, Göcke is not offering an accurate interpretation of what theists and panentheists themselves actually believe. As Lataster puts it, Göcke is only interested in a God of his own making. ${ }^{77}$

However, Göcke can offer a rejoinder to this. As already noted, Göcke finds it difficult to discern what panentheism is by examining what panentheists themselves say. In a series of papers between him and Lataster over panentheism, Göcke complains that Lataster will not state what the unique, defining features are of panentheism. Göcke's attempt at demarcating panentheism need not be taken as an accurate description of what panentheists say since it is difficult to figure out what they are saying. Instead, it should be taken as a plausible prescription for what panentheists should say. ${ }^{78}$ So, Göcke could admit that not all panentheists hold to the necessity of the universe but insist that they should. Why? Because this is the best way to demarcate panentheism from its theistic rivals.

With this in mind, Göcke could offer a rejoinder like this. He could say that my arguments do not establish that theism and panentheism cannot be demarcated. Instead, I only establish that classical and neo-classical theism cannot be demarcated from panentheism. Why? Classical and neo-classical theism logically entail that God must

\footnotetext{
75 Thomas Jay Oord, 'An Open Theology Doctrine of Creation and Solution to the Problem of Evil,' in (Oord 2009).

76 (Clayton, God and Contemporary Science 1997, 93-96).

77 (Lataster, The Attractiveness of Panentheism-A Reply to Benedickt Paul Gocke, 2014).

78 (Gocke, Reply to Raphael Latester, 2014b).
} 
create the universe; the universe necessarily exists. So even though thinkers like Aquinas, Rogers, and Kraay do not claim to be panentheists, their views logically entail panentheism. Yet open theism, with its denial of divine simplicity and stronger emphasis on divine freedom, does not entail that God must necessarily create the universe. So open theism is distinct from panentheism.

This might be a way to go, but it does not seem to me to justify the claims of panentheists. I am incredibly sympathetic to Göcke's prescriptive approach, but I believe that whatever prescriptive definition one gives, it must capture the many claims that panentheists make. For instance, panentheists claim that their model of God offers one in which God and the universe are more radically and intimately related than on theism. The modal status of the universe seems irrelevant to this claim. One could say that God is timeless or temporal, strongly immutable or weakly immutable, and so on, and yet affirm the necessity of the universe.

It seems to me that this fails for a similar reason as the claim that the universe is God's body fails. Neither demarcation says anything unique about the nature of God, and panentheism is supposed to be making a unique claim about the nature of God. All of the demarcating work is being done on the side of creation. Just change the definition of 'body' and the universe will count as God's body or just change the modal status of the universe, and we have panentheism. Neither of these says anything unique about God, and that is what is needed for a model of God to be demarcated from other rival models of God.

\section{Another Attempt at Demarcating Panentheism}

Perhaps there are some possible options open to the panentheist. In this section, I shall lay out one possibility that will need to be explored in future work. Again, I am incredibly sympathetic to Göcke's prescriptive approach to panentheism. However, I am not convinced that his proposal captures the claims that panentheists themselves wish to make nor does it really seem to carve reality at its joints. What is needed is a proposal that (a) says something unique about God that other models do not say and (b) that illuminates the claim that the universe is in God.

Here is my attempt to offer a prescriptive definition of panentheism. With regards to condition (a), a panentheist could make space and time attributes of God. There are passages in thinkers like Nicole Oresme, Pierre Gassendi, Isaac Newton, and Samuel Clarke where they seem to equate God's omnipresence and eternality with absolute space and time. ${ }^{79}$ Yet, it is difficult to establish that they truly intend to say this. For instance, in some of Clarke's letters he clarifies this point. It is not that space and time are attributes of God. Instead, space and time are necessary concomitants of God's existence. ${ }^{80}$ Perhaps a panentheist should not make this clarification. Instead, a panentheist should insist that absolute space and time are attributes of God. ${ }^{81}$ Absolute space and time exist regardless of the physical and temporal things that are contained within them.

\footnotetext{
${ }^{79}$ (Oresme, 1968) (Charleton, 1654).

${ }^{80}$ (Clarke, 1998, 122-3).

${ }^{81}$ Thanks to J.T. Turner for continually pushing me on this point.
} 
For the sake of clarity, a particular distinction should be noted. Sometimes, a distinction is made between metaphysical space and time and physical space and time. Metaphysical space and time are said to exist regardless of the measurements we try to make of them and regardless of whether or not physical objects exist. Whereas physical space and time exist if and only if physical objects exist. ${ }^{82}$ Sometimes, metaphysical space and time are developed in terms of a hyperspace and a hypertime that physical space and time exist within. ${ }^{83}$ Given this distinction, the panentheist would be saying that absolute space and time are to be construed as metaphysical space and time. These are divine attributes, whereas physical space and time are not. When God creates a universe, God creates physical space and time. Physical space and time exist within metaphysical space and time/God.

What can be said about the way of demarcating panentheism? This satisfies condition (a) because it makes a unique claim about God that other models of God do not make. Classical theists typically claim that God creates space and time and as such space and time are not attributes of God. Some neo-classical and open theists affirm that absolute time is a necessary concomitant of God's being (e.g. Clarke and Swinburne), but they do not insist that absolute space and time are divine attributes. So this allows the panentheist a way to demarcate her understanding of God from theists.

What about pantheism? Can the panentheist demarcate herself from pantheism? Yes. The panentheist should not insist that God and the universe are the same substance. She can maintain that God and the universe are distinct substances. God and the universe are not identical. The universe is not identical to absolute space and time. The universe exists in absolute space and time. In identifying God and the universe, the pantheist is collapsing the distinction between absolute/metaphysical and physical space and time. The panentheist will instead insist upon this distinction.

With regards to satisfying condition (b), the panentheist can say that the modal status of the universe is irrelevant to capturing the 'in' of panentheism. She is free to affirm the necessity or the contingency of the universe. However, she will affirm that the universe is literally in God because the universe is spatially and temporally located in God. The universe is located in absolute space and time, and space and time are divine attributes. This can actually capture the 'in' of panentheism in metaphysical, instead of metaphorical, terms. The universe is literally in God since space and time are attributes of God. If one follows Clarke and says that space and time are necessary concomitants of God's existence, she will not be a panentheist. She will not be saying that we are literally in God, just in space and time. By affirming that space and time are divine attributes, the panentheist will be asserting that the universe is literally in God.

I believe that this proposal could be fleshed out to capture the hard core of panentheism as well as the diversity within panentheism. It gives substantive content to the claim that the universe is not identical to God, but that it is in God. Panentheists could use this to justify their claims that their model of God is one in which God is more radically and intimately related to the universe than the theistic God. It also allows panentheists to continue to disagree over the modal status of the universe. It is not clear to me how the panentheist can use this to justify her claim that her model of God is

\footnotetext{
${ }_{82}$ For more on the distinction between metaphysical and physical space and time see (Mullins, 2016).

${ }^{83}$ (Hudson, 2005) (Hudson, 2014).
} 
more scientific than other rivals, but I have independent doubts about this claim anyway.

Naturally, this model raises many questions and potential objections. I see this as an advantage because it satisfies one of Göcke's intentions for demarcating panentheism. By clearly demarcating panentheism, one can develop arguments for the truth or falsity of panentheism. This cannot be done if panentheism remains vague and nebulous. For Göcke, the truth or falsity of panentheism involved examining the modal status of the universe. On my proposed model of panentheism, this will involve examining the existence of absolute space and time, as well as arguments for identifying absolute space and time as divine attributes. This provides a clear path for future explorations into the validity of panentheism.

\section{Conclusions}

I have examined two attempts to demarcate panentheism from theism and pantheism and have argued that both fail. If panentheists wish to maintain that their view is somewhere in between theism and pantheism, they need to offer a clear way of demarcating their position from its rivals. I sketched a possible way for panentheists to demarcate their position, but it remains to be seen whether or not panentheists will wish to affirm this proposal. If they reject this proposal, I am left to ask once again, 'Is panentheism actually a position at all?' Perhaps it is, but I shall leave it to the panentheists to explain how this is the case.

Acknowledgments The author would like to thank Gocke for helpful feedback on an earlier draft of this paper.

Open Access This article is distributed under the terms of the Creative Commons Attribution 4.0 International License (http://creativecommons.org/licenses/by/4.0/), which permits unrestricted use, distribution, and reproduction in any medium, provided you give appropriate credit to the original author(s) and the source, provide a link to the Creative Commons license, and indicate if changes were made.

\section{References}

Achtner, W. (2005). Infinity in science and religion: the creative role of thinking about infinity. Neue Zeitschrift fur Systematisch Theologie und Religionsphilosophie, 47, 392-411.

Aquinas, T. (1993). In J. N. Deely (Ed.), The collected works of St. Thomas Aquinas. Electronic edition. Charlottsville: InteLex Corporation.

Arminius, J. (1986). The works of James Arminius (Vol. 2). (J. Nichols, Trans.) London: Baker Book House Company.

Augustine, S. (1958). City of God. (G. G. Walsh, D. B. Zema, G. Monahan, \& D. J. Honan, Trans.) New York: Double Day.

Augustine, S. (1991). The Trinity. (E. Hill, Trans.) Hyde Park: New City Press.

Barua, A. (2010). God's body at work: Ramanuja and panentheism. International Journal of Hindu Studies, 14, 1-30.

Biernacki, L., \& Clayton, P. (Eds.). (2014). Panentheism across the world's traditions. Oxford: Oxford University Press.

Blowers, P. M. (2012). Drama of the divine economy: creator and creation in early Christian theology and piety. Oxford: Oxford University Press.

Boethius. (n.d.). Consolations of philosophy. 
Callender, C. (Ed.). (2011). The Oxford handbook of philosophy of time. Oxford: Oxford University Press.

Charleton, W. (1654). Physiologia Epicuro-Gassendo-Charltoniana, or, A Fabrick of Science Natural, Upon the Hypothesis of Atoms Founded by Epicurus, Repaired by Petrus Gassendus, Augmented by Walter Charleton. London: Tho. Newcomb.

Charnocke, S. (1682). Several discourses upon the existence and attributes of God. London: D. Newman, T. Cockerill, Benj. Griffin, T. Simmons, and Benj. Alson

Clarke, S. (1998). In E. Vailati (Ed.), A demonstration of the being and attributes of God and other writings. Cambridge: Cambridge University Press.

Clayton, P. (1997). God and contemporary science. Edinburgh: Edinburgh University Press.

Clayton, P. (2000). The problem of God in modern thought. Grand Rapids: Wm. B. Eerdmans Publishing Co.

Clayton, P. (2010). Panentheisms east and west. Sophia, 49, 183-191.

Clayton, P., \& Peacocke, A. (Eds.). (2004). In whom we live and move and have our being: panentheistic reflections on God's presence in a scientific world. Grand Rapids: Wm. B. Eerdmans Publishing Co.

Clayton, P., \& Simpson, Z. (Eds.). (2006). The Oxford handbook of religion and science. New York: Oxford University Press.

Cooper, J. W. (2006). Panentheism: the other God of the philosophers. Grand Rapids: Baker Academic.

Craig, W. L. (2001). God, time, and eternity. London: Kluwer Academic Publishers.

Cross, R. (2005). Duns Scotus on God. Burlington: Ashgate Publishing.

Davies, B., \& Evans, G. (Eds.). (2008). Anselm of Canterbury: the major works. New York: Oxford University.

Diller, J., \& Kasher, A. (Eds.). (2013). Models of God and alternative ultimate realities. New York: Springer.

Dyer, L.-A. (2010). Transcendent and immanent eternity in Anselm's monologion. Filosophia Unisinos, 11, 261-286.

Feinberg, J. S. (2001). No one like him: the doctrine of God. Wheaton: Crossway Books.

Flint, T. P. (1998). Divine providence: the molinist account. Ithica: Cornell University Press.

Fox, R. (2006). Time and eternity in mid-thirteenth-century thought. Oxford: Oxford University Press.

Gocke, B. P. (2013). Panentheism and classical theism. Sophia, 52, 61-75.

Gocke, B. P. (2014a). A theory of the absolute. London: Palgrave Macmillan.

Gocke, B. P. (2014b). Reply to Raphael Latester. Sophia, 53, 397-400.

Gocke, B. P. (2015). Another reply to Raphael Lataster. Sophia, 54, 99-102.

Hasker, W., Oord, T. J., \& Zimmerman, D. (Eds.). (2011). God in an open universe: science, metaphysics, and open theism. Eugene: Wipf and Stock Publishers.

Hawley, K. (2001). How things persist. Oxford: Oxford University Press.

Hegel, G. (1975). Logic: being part one of the encyclopedia of the philosophical sciences. Oxford: Oxford University Press.

Helm, P. (2010). Eternal God: a study of God without time (2nd ed.). Oxford: Oxford University Press.

Hudson, H. (2005). The metaphysics of hyperspace. Oxford: Oxford University Press.

Hudson, H. (2014). The fall and hypertime. Oxford: Oxford University Press.

Hutchings, P. (2010). Postlude: panentheism. Sophia, 49, 297-300.

Keating, J. F., \& White, T. J. (Eds.). (2009). Divine impassibility and the mystery of human suffering. Cambridge: Wm. B. Eerdmans Publishing Co.

Kraay, K. J. (2010). Theism, possible words, and the multiverse. Philosophical Studies, 147, 355-368.

Kraay, K. J. (2011). Theism and modal collapse. American Philosophical Quaterly, 48, 361-386.

Kvanvig, J. L. (Ed.). (2008). Oxford studies in philosophy of religion (Vol. 1). New York: Oxford University Press.

Kvanvig, J. L. (Ed.). (2009). Oxford studies in philosophy of religion (Vol. 2). New York: Oxford University Press.

Lataster, R. (2014). The attractiveness of panentheism-a reply to Benedickt Paul Gocke. Sophia, 53, 389-395.

Lataster, R. (2015). Theists misrepresenting panentheism-another reply to Benedikt Paul Gocke. Sophia, 54, 93-98.

Leslie, J. (2001). Infinite minds: a philosophical cosmology. Oxford: Oxford University Press.

Lodzinski, D. (1998). The eternal act. Religious Studies, 34, 325-352.

Lombard, P. (2007). The sentences book 1: the mystery of the trinity. (G. Silano, Trans.) Ontario: Pontifical Institute of Mediaeval Studies.

Mander, W. J. (2000). Omniscience and pantheism. Heythrop Journal, 41, 199-208.

Mander, W. J. (2002). Does God know what it is like to be me? Heythrop Journal, 43, 430-443.

Mawson, T. (2005). Belief in God: an introduction to the philosophy of religion. Oxford: Oxford University Press.

Mawson, T. (2006). God's body. The Heythrop Journal, 47, 171-181. 
McCann, H. J. (2012). Creation and the sovereignty of God. Bloomington: Indiana University Press.

Molina, L. D. (1988). On divine foreknowledge: part IV of the Concordia. (A. Freddoso, Trans.) Ithaca: Cornell University Press.

Morris, T. V. (1991). Our idea of God: an introduction to philosophical theology. Downers Grove: InterVarsity Press.

Mullins, R. (2013). Simply impossible: a case against divine simplicity. Journal of Reformed Theology, 7 , 181-203.

Mullins, R. (2016). The end of the timeless God. Oxford: Oxford University Press.

Mullins, R. (Forthcoming). Divine perfection and creation. The Heythrop Journal.

Nicole Oresme and the medieval geometry of qualities and motions. (1968). (M. Clagett, Trans.) London: The University of Wisconsin Press.

O'Connor, T. (2012). Theism and ultimate explanation: the necessary shape of contingency. Malden: Blackwell Publishing Ltd.

Oord, T. J. (Ed.). (2009). Creation made free: open theology engaging science. Eugene: Pickwick Publications.

Oppy, G. (2014). Describing gods: an investigation of divine attributes. Cambridge: Cambridge University Press.

Oppy, G., \& Trakakis, N. (Eds.). (2009). The history of western philosophy of religion volume 1: ancient philosophy of religion. Durham: Acumen Publishing Limited.

Oresme, N. (1968). Le Livre du ciel et du monde. (A. D. Menut, A. J. Denomy, Eds., \& A. D. Menut, Trans.) London: The University of Wisconsin Press.

Pasnau, R. (2011). Metaphysical themes: 1274-1671. Oxford: Oxford University Press.

Peacocke, A. (2007). In P. Clayton (Ed.), All that is: a naturalistic faith for the twenty-first century. Minneapolis: Fortress Press.

Peters, T. (2007). Models of God. Philosophia, 35, 273-288.

Rhoda, A. R., Boyd, G. A., \& Belt, T. G. (2006). Open theism, omniscience, and the nature of the future. Faith and Philosophy, 23, 432-459.

Rogers, K. A. (1997). The anselmian approach to God and creation. Lewiston: The Edwin Mellen Press.

Rogers, K. A. (2000). Perfect being theology. Edinburgh: Edinburgh University Press.

Rogers, K. A. (2006). Anselm on eternity as the fifth dimension. Saint Anselm Journal, 3, 1-8.

Rogers, K. A. (2007a). Anselm and his Islamic contemporaries on divine necessity and eternity. American Catholic Philosophical Quarterly, 81, 373-393.

Rogers, K. A. (2007b). Anselmian eternalism: the presence of a timeless God. Faith and Philosophy, 24, 3-27.

Scotus, J. D. (1975). God and creatures: the quodlibetal questions. (F. Alluntis, \& A. B. Wolter, Trans.) Princeton: Princeton University Press.

Shults, F. L. (2005). Reforming the doctrine of God. Grand Rapids: Wm. B. Eerdmans Publishing Co.

Spinoza, B. (1910). Spinoza's ethics and on the correction of the understanding. (A. Boyle, Trans.) New York: J.M. Dent \& Sons LTD.

Stewart, M. Y. (Ed.). (2010). Science and religion in dialogue. Malden: Blackwell Publishing Ltd.

Swinburne, R. (1977). The coherence of theism. Oxford: Oxford University Press.

Taliaferro, C. (1989). The passibility of God. Religious Studies, 25, 217-224.

Tapp, C., \& Runggaldier, E. (Eds.). (2011). God, eternity, and time. Surrey: Ashgate Publishing Limited.

Turretin, F. (1992). Institutes of elenctic theology (Vol. 1). (J. T. Jr., Ed., \& G. M. Giger, Trans.) Phillipsburg: Presbyterian and Reformed Publishing Company.

Ware, B. (Ed.). (2008). Perspectives on the doctrine of God: 4 views. Nashville: B \& H Publishing.

Wolterstorff, N. (2010). In T. Cuneo (Ed.), Inquiring about God: selected essays, volume 1. New York: Cambridge University Press. 